\title{
ALFATHESIN AND ETOMIDATE FOR MINOR OUTPATIENT ANAESTHESIA
}

\author{
David H. Morison, Geoffrey L. Dunn and Ama de Graft-Johnson
}

\begin{abstract}
Etomidate was compared with alfathesin for induction and maintenance of anaesthesia in a double-blind fashion in 48 fit patients undergoing minor gynaecological opcrations as outpatients. The patients were randomized to receive either etomidate $0.3 \mathrm{mg} \mathrm{kg}^{-1}$ or alfathesin $75 \mu \mathrm{l} \cdot \mathrm{kg}^{-1}$ as intravenous induction agents. All patients received fentanyl 1 $\mu \mathrm{g} \cdot \mathrm{kg}^{-1}$ and breathed 70 per cent nitrous oxide in oxygen. Cardiovascular changes were minimal in both groups and there was less depression of minute volume with etomidate. The incidence of side effects including pain upon injection, involuntary movements, and postoperative nausea and vomiting was higher following etomidate. Recovery was equally rapid in both groups. No adverse reactions were seen. Alfathesin would appear to be preferable to etomidate as an induction and maintenance agent in unpremedicated fit outpatients undergoing minor gynaecological operations.
\end{abstract}

Key WoRDS; ANAESThETICS, Intravenous, alfathesin, etomidate; SURGERY, outpatient gynaecology.

ETOMIDATE, an imidazole derivative, is a shortacting non-barbiturate intravenous anaesthetic. It may offer advantages for outpatient surgery because of minimal cardiorespiratory changes as well as rapid recovery, ${ }^{1-3}$ although some authors have reported a high incidence of pain on injection, involuntary movements, and postoperative nausea and vomiting. ${ }^{4,5}$ In the present study, etomidate (formulated in 35 per cent propylene glycol) was compared in a doubleblind format with alfathesin for induction and maintenance of anaesthesia in patients undergoing outpatient operations. The objective of this study was to compare the two drugs in terms of clinical efficacy, cardiorespiratory changes, side effects, and recovery characteristics.

\section{METHODS}

Institutional approval of the protocol was obtained and all patients gave informed written

Dayid H. Morison, M.B., Ch.B., F.R.C.P.(C), Associate Professor; Geoffrey L. Dunn, M.B., B.S., F.R.C.P.(C), F.F.A.R.C.S., Associate Professor; Ama deGraft-Johnson, M.B., Ch.B., Clinical Fellow: Section of Anaesthesia. Chedoke-McMaster Hospitals and Department of Anaesthesia, McMaster University, Hamilton, Ontario, L8N 3Z5. .

Presented in part at the Annual Meeting of the Canadian Anacsthetists' Society, Halifax, Nova Scotia, June 1981 .

Supported by a grant-in-aid from McNeil Laboratories. 622

Can. Anaesth. Soc. J., vol. 29, no. 6, November 1982 consent. Forty-eight female patients classified as ASA I, between 16 and 40 years of age, weighing between 45 and $90 \mathrm{~kg}$ and scheduled for minor gynaecological operations were studied. No premedication was given but all patients received fentanyl $1 \mu \mathrm{g} \cdot \mathrm{kg}^{-1}$ intravenously one minute before induction of anaesthesia.

Patients were randomly assigned, within blocks of eight, to one of two anaesthetic techniques. Group A (24 patients) were induced with etomidate $0.3 \mathrm{mg} \cdot \mathrm{kg}^{-1}$ and Group B (24 patients) with alfathesin $75 \mu \mathrm{kg}^{-1}$, both injected intravenously over 45 seconds into a previously established intravenous infusion. Anaesthesia was maintained with 70 per cent nitrous oxide with oxygen with spontaneous breathing through a face mask. Increments of etomidate or alfathesin equal to 25 per cent of the induction dose were injected if indicated on clinical grounds, i.e. movement in response to a surgical stimulus. An experienced anaesthetist unaware of which agent was being used acted as observer and "blindness" was achieved by pre-dilution of alfathesin with normal saline to be equivolumetric and of identical appearance to etomidate.

In order to determine whether the incidence of pain on injection was affected by venous site, the preoperative intravenous cannula was inserted into either an arm or hand vein, the site being determined by chance.

Systolic and diastolic blood pressures and 
pulse rate were measured preoperatively and every minute during anaesthesia using a Dinamap 845 recorder. Minute volume and respiratory rate were recorded at the same intervals using a Wright's electronic respirometer. The observer assessed side effects, which included pain upon injection, incidence of apnoea, involuntary movements, and respiratory disturbances. Recovery, taken from termination of anaesthesia, was recorded as the time to "open eyes" and to recall "date of birth". "Street fitness" was assessed using a modified Fay scoring system. ${ }^{6}$ Postoperative side effects were assessed by two patient questionnaires, one of which was completed before leaving hospital and the other on the day following anaesthesia.

Cardiorespiratory variables were analyzed by analysis of variance and comparisons at specific time points were made using the independent " $t$ " test. Ordinal data were compared using a $2 \times 2$ or $2 \times 3$ Fischer Exact test. A level of $p \leqslant 0.05$ was considered to be statistically significant.

\section{RESULTS}

The groups were similar with respect to age and weight and there was no difference between the two groups in the times for loss of response, loss of eyelash reflex and duration of the anaesthesia (Table I). The mean number of increments given were 1.83 in the etomidate and 1.21 in the alfathesin group and this difference was not statistically significant

The cardiorespiratory changes are shown in Figure 1. The pulse rate was lower in the etomidate group at all times and there was a significant overall difference between the groups $(\mathrm{p}=0.006)$. With etomidate, the systolic blood pressure was higher at the first and second minutes after induction. Diastolic blood pressure was significantly higher $(p=0.002)$ in the etomidate group throughout the study. The respiratory rate showed a marked progressive but similar increase in both groups. The minute volume increased progressively after the second minute with etomidate, whereas with alfathesin it decreased following induction of anaesthesia, returning to the preoperative value at four minutes and thereafer rose progressively. At all time points minute volume was significantly higher in the etomidate than in the alfathesin group ( $p=0.015$ ).

The incidence of side effects is shown in Table II. Pain on injection, although not observed in the alfathesin group, occurred in 10 patients ( 42
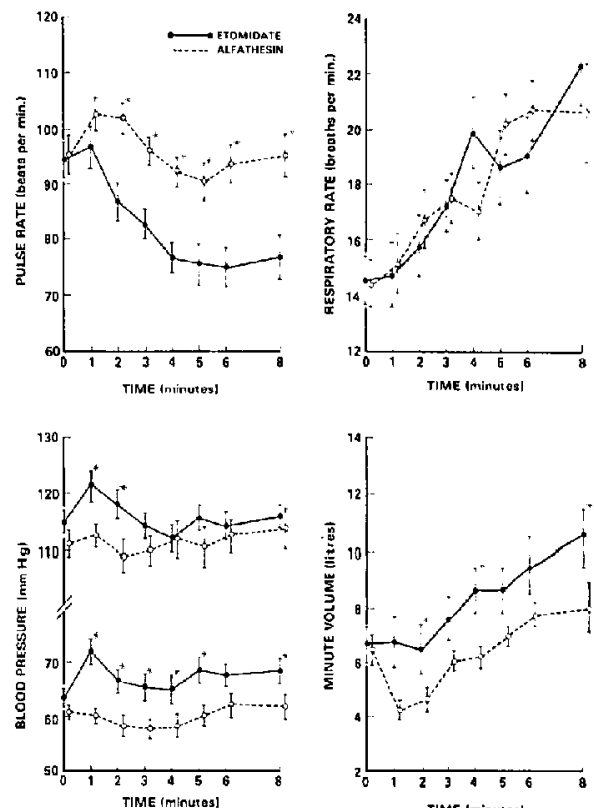

FIGURE 1 Cardiorespiratory variables following induction of anaesthesia with etomidate $0.3 \mathrm{mg} \cdot \mathrm{kg}^{-7}$ or alfathesin $75 \mu \mathrm{l} \cdot \mathrm{kg}^{-1}$. Values are plotted as mean \pm 1 SEM. * denotes significant difference between groups at $p<0.05$ level.

per cent) who received etomidate $(\mathrm{p}=0.0006)$. This was more frequent in those patients receiving etomidate into a hand vein ( 8 out of 14) versus an arm vein ( 2 out of 10 ) but this difference was not statistically significant $(\mathrm{p}=$ 0.1 ). The incidence of apnoea following induction was slightly higher in the alfathesin group but the mean apnoeic period was significantly longer with etomidate $(42.4 \pm 25.3 \mathrm{sec})$ than with alfathesin $(19.9 \pm 9.3 \mathrm{sec})(p=0.03)$. Involuntary movements occurred more frequently following etomidate than alfathesin but this difference was not statistically significant $(\mathrm{p}=$ 0.07 ). Respiratory disturbances comprising hiccough, coughing, and mild laryngospasm occurred with similar incidence in both groups. In the recovery room, nine patients (38 per cent) vomited after etomidate compared to two ( 8 per cent) after alfathesin $(p=0.04)$.

Recovery times (Table III) were comparable for both groups.

The response rate from the questionnaires completed after discharge from hospital was high at 75-79 per cent (Table IV). The two groups were comparable in terms of vomiting 
TABLE I

Patient and Anaesthetic Variables Expressed as MEan \pm 1 SEM

\begin{tabular}{lccccc}
\hline \hline & $\begin{array}{c}\text { Age } \\
\text { (years) }\end{array}$ & $\begin{array}{c}\text { Weight } \\
(\mathrm{kg})\end{array}$ & $\begin{array}{c}\text { Loss of response } \\
(\mathrm{sec})\end{array}$ & $\begin{array}{c}\text { Loss of eyelash } \\
\text { reflex } \\
(\mathrm{sec})\end{array}$ & $\begin{array}{c}\text { Duration of } \\
\text { Anaesthesia } \\
\text { (min) }\end{array}$ \\
\hline Etomidate & $23.7 \pm 1.4$ & $62.0 \pm 2.4$ & $50.9 \pm 1.8$ & $77.3 \pm 5.7$ & $8.8 \pm 1.1$ \\
Alfathesin & $23.0 \pm 1.2$ & $60.0 \pm 1.8$ & $45.7 \pm 2.1$ & $62.2 \pm 2.5$ & $8.3 \pm 0.9$ \\
\hline
\end{tabular}

TABLE II

InCIDENCE of Side EfFects (Recorded in Hospital) With Each ANaesthetic Technique

\begin{tabular}{|c|c|c|c|c|c|c|}
\hline & \multirow{2}{*}{$\begin{array}{l}\text { Pain Upon } \\
\text { Injection }\end{array}$} & \multirow{2}{*}{$\begin{array}{l}\text { Apnoea } \\
\text { Following } \\
\text { Induction }\end{array}$} & \multirow{2}{*}{$\begin{array}{l}\text { Involuntary } \\
\text { Movements }\end{array}$} & \multicolumn{3}{|c|}{ Respiratory Disturbances } \\
\hline & & & & Induction & Maintenance & Vomiting \\
\hline $\begin{array}{l}\text { Etomidate } \\
\text { Alfathesin }\end{array}$ & $10(42 \%)$ & $\begin{array}{l}5(21 \%) \\
9(38 \%)\end{array}$ & $\begin{array}{r}12(50 \%) \\
6(25 \%)\end{array}$ & $\begin{array}{l}3(13 \%) \\
3(13 \%)\end{array}$ & $\begin{array}{l}7(29 \%) \\
6(25 \%)\end{array}$ & $\begin{array}{l}9(38 \%) \\
2(8 \%)\end{array}$ \\
\hline $\begin{array}{l}\text { Statistical Significance } \\
\text { (p value) }\end{array}$ & 0.0006 & 0.34 & 0.07 & & J.S. & 0.036 \\
\hline
\end{tabular}

TABLE III

Recovery Times Following the Two Anaesthetic Techniques EXPRESSED AS MEAN \pm 1 SEM

\begin{tabular}{lccc}
\hline \hline & $\begin{array}{c}\text { "Eyes Open" } \\
\text { (min) }\end{array}$ & $\begin{array}{c}\text { "Date of Birth" } \\
\text { (min) }\end{array}$ & $\begin{array}{c}\text { "Street Fitness" } \\
\text { (hours) }\end{array}$ \\
\hline Etomidate & $2.83 \pm 0.42$ & $5.23 \pm 0.68$ & $3.30 \pm 0.15$ \\
Alfathesin & $2.87 \pm 0.35$ & $5.76 \pm 0.60$ & $3.25 \pm 0.15$ \\
\hline
\end{tabular}

TABLE IV

Incidence of Side Effects (Expressed as Percentage of Respondents) Occurring After Discharge From Hospital as Elicited by Follow-Up Questionnaire

\begin{tabular}{lcccc}
\hline \hline & $\begin{array}{c}\text { Questionnaire } \\
\text { Response }\end{array}$ & Vomiting & $\begin{array}{c}\text { Drowsy on Evening } \\
\text { of Discharge }\end{array}$ & $\begin{array}{c}\text { Pain at I.V. Site } \\
\text { (Morning After Operation) }\end{array}$ \\
\hline Etomidate & $19(79 \%)$ & $3(16 \%)$ & $11(58 \%)$ & $9(47 \%)$ \\
Alfathesin & $18(75 \%)$ & $1(6 \%)$ & $7(39 \%)$ & $8(44 \%)$ \\
\hline
\end{tabular}

and drowsiness. There was a tendency for patients to rate the quality of anaesthesia higher with alfathesin ( 67 per cent excellent) than with etomidate ( 46 per cent excellent) but this was not statistically significant.

\section{Discussion}

In this study, etomidate and alfathesin were compared as intravenous induction and maintenance agents in unpremedicated outpatients presenting for minor gynaecological procedures. A standardized anaesthetic technique was used and a double-blind design was facilitated by diluting alfathesin to be equi-volumetric with etomidate. Alfathesin was chosen as the standard for comparison with etomidate because it is the authors' preferred induction agent in outpatient surgery. ${ }^{7}$ Fentanyl was administered intravenously before etomidate or alfathesin since it has been shown to reduce the dose of induction agent, has little effect upon recovery and will decrease the tachycardia, tachypnoea and hyperventilation seen with alfathesin alone. . $^{3,8}$

Pulse rate decreased following induction with etomidate, and was always lower than with 
alfathesin. It is likely that the preoperative pulse rate in both groups was somewhat increased from normal resting values due to apprehension. The fall following etomidate may therefore represent a return to a normal level rather than a specific vagotonic effect of etomidate itself. Systolic blood pressure following induction with etomidate was initially increased, thereafter returning to preoperative levels. Diastolic blood pressure with etomidate followed a similar pattern but remained slightly elevated throughout anaesthesia. In the alfathesin group, there was little change in either systolic or diastolic blood pressure throughout anaesthesia. It is difficult to interpret these small relative differences between the two drugs because of concurrent surgical stimulation and the use of the lithotomy position for all patients. These findings would be consistent with previous studies which indicate that alfathesin ${ }^{8,9}$ decreases, and etomidate ${ }^{1,10}$ has little effect on, peripheral resistance.

Respiratory rate increased progressively following induction with both etomidate and alfathesin and this is likely due to light anaesthesia in the presence of surgical stimulation. Minute volume was consistently higher with etomidate and would suggest that etomidate produced less respiratory depression than alfathesin when administered in conjunction with fentanyl. ${ }^{8.11}$

Overall, the quality of induction of anaesthesia was superior with alfathesin. Etomidate produced local pain in 42 per cent of patients, although this occurred less frequently when an arm vein rather than a hand vein was used for injection. Although this difference did not reach statistical significance, it is suggested that injection into a larger vein is preferable. Pain on injection was not a feature of alfathesin induction. Similarly, there was a trend towards a higher incidence of involuntary movements with etomidate when compared to alfathesin. Respiratory disturbances occurred with equal frequency with both drugs.

Recovery was equally rapid following both etomidate and alfathesin. However, there was a significantly higher incidence of vomiting in the early recovery period following etomidate. This is consistent with the findings of previous studies which have reported a relatively high incidence of post-operative vomiting following the use of etomidate. ${ }^{2-5}$ Late recovery was uneventful in both groups.

Adverse reactions to alfathesin of a hypersensitivity type have been reported to vary between 1 in 608 cases $^{12}$ to 1 in $11,000,,^{13}$ whereas such events have rarely been reported with etomidate. No such adverse reactions were seen in the present study but this is not surprising in view of the small number of cases.

In conclusion, the use of etomidate was accompanied by marginally less depression of minute volume and by a higher incidence of pain on injection, involuntary movements, and postoperative vomiting than with alfathesin. Previous studies have indicated that etomidate produces less cardiovascular depression than alfathesin, but the present study did not show any clinically important advantage in this respect for either drug. It is therefore suggested that alfathesin is preferable to etomidate for induction and maintenance of anaesthesia in unpremedicated, fit patients undergoing minor gynaecological procedures on an outpatient basis.

\section{ACKNOWLEDGEMENT}

The authors wish to thank Mrs. J. Magee for her assistance in the performance of the study and Ms. S. Seaman for manuscript preparation.

\section{REFERENCES}

1. Gooding, J. M. \& Crossen, G. Effect of etomidate on the cardiovascular system. Anesth. Analg. 56: 717 (1977).

2. FRaGeN, R.J. \& Caldwell, N. Comparison of a new formulation of etomidate with thiopentalside effects and awakening times. Anesthesiology 50: 242 (1979).

3. Horrigan, R.W., MOYers, J.R., JOHNSON, B.H., Eger, E.I., II, Margolis, A. \& GoldSMITH, S. Etomidate vs. thiopental with and without fentanyl - a comparative study of awakening in man. Anesthesiology 52: 362 (1980).

4. Zacharias, M. Clarke, R.S.J., DuNDEe, J.W. \& JoHNSTON, S.B. Evaluation of three preparations of etomidate. Br. J. Anaesth. 50 925 (1978),

5. Yelavich, P.M. \& Holmes, C.McK. Etomidate: a foreshortened clinical trial. Anaesth. Intens. Care 8: 479 (1980).

6. FAY, M.R. Nursing process in the recovery room. AORN Journal 24: 1079 (1976).

7. DunN, G.L., Houlton, P.J., Morison, D.H. \& RAJAGOPLAN, R. A comparative assessment of alfathesin for use in outpatient anaesthesia. Can. Anaesth. Soc, J, 25: 125 (1978).

8. Dunn, G.L., Houlton, P.J., Morison, D.H \& Rajagopalan, $R$. The influence of fentanyl on an alfathesin infusion technique. Can. Anaesth. Soc. J. 25: 331 (1978).

9. Savege, T.M., Foley, E.I., Colltas, R.J. Walton, B., Strunin, L., Simpson, B.R. \& ScoTT, D.F. CT1341: some effects in man. Anaesthesia 26: 402 (1971)

10. Criado, A., Maseda, J., Navarro, E. Escarpa, 
A. \& Avello, F. Induction of anaesthesia with etomidate: haemodynamic study of 36 patients. Br. J. Anaesth. 52: 803 (1980)

11. Morgan, M., Lumley, J. \& Whitwam, J,G. Respiratory effects of etomidate. Br. J. Anaesth. 49: 233 (1977).

12. BEAmISH, D. \& Brown, D.T. Adverse responses to I.V. anaesthetics. Br. J. Anaesth. 53: 55 (1981).

13. Clarke, R.S.J., Dundee, J.W., Garrett, R.T., MCARDLE, G.K. \& SUtTon, J.A. Adverse reactions to intravenous anaesthetics. Br. J. Anaesth. 47: 575 (1975).

RÉSUMÉ

On a comparé l'étomidate à l'alfatésin pour l'induction et le maintien de l'anesthésie sur 48 patientes en bon état qui subissaient une intervention gynécologique mineure. Les patientes reparties au hasard ont reçu étomidate $0.3 \mathrm{mg} \cdot \mathrm{kg}^{-1}$ ou alfatésin $75 \mathrm{ml} \cdot \mathrm{kg}^{-1}$ par la voie veineuse à l'induction. Toutes les patients ont reçu fentanyl $1 \mu \mathrm{g} \cdot \mathrm{kg}^{-1}$ et respiraient du protoxyde d'azote à 70 pour cent dans l'oxygène. Le retentissement cardiovasculaire a été minime dans les deux groupes et le volume courant a été moins déprimé avec l'étomidate. Les effets secondaires consistaient en de la douleur lors de l'injection, des mouvements involontaires et des nausées et vomissements qui étaient plus fréquents avec l'étomidate. Le réveil a été rapide dans les deux groupes. Aucun accident fâcheux n'a été constaté. L'alfatésin semble préférable à l'étomidate comme agent d'induction et de maintien chez des patientes ambulantes et en bon état pour la chirurgie gynécologique mineure. 